\title{
AN EMPIRICAL ANALYSIS OF THE RELATIONSHIP BETWEEN ECONOMIC GROWTH AND UNEMPLOYMENT: CASE OF SELECTED DEVELOPING COUNTRIES $^{12}$
}

Article Submission Date: 20.09.2021

Hatice Nehrin TUNALI SARI

Phd Student - 100/2000 CoHE PHd

Scholarship

Uludağ University

Faculty of Economics and

Administrative Sciences,

Bursa, Turkey

ntunali@uludag.edu.tr

ORCID ID: 0000-0002-1297-6196
Accepted Date: 02.11.2021

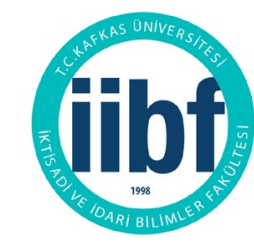

Kafkas University Economics and Administrative Sciences Faculty KAUJEASF

Vol. 12, Issue 24, 2021

ISSN: $1309-4289$

E - ISSN: 2149-9136

\section{ABSTRACTI The main}

purpose of this study is to examine whether there is a long-term relationship between the economic growth and unemployment. The unemployment rate belonging to 2005:Q1 2019:Q1 period of Hungary, Mexico, Poland, Chile and Turkey taking place in economically developing country status and quarterly data belonging to Real Gross Domestic Product (RGDP) macroeconomic indicators have been used in the study. The existence of the relationship between these two variables is tested by benefiting from the panel data analysis methods. It has been determined that there was no long-term relationship between the unemployment and growth in these countries during the said period according to the findings obtained from the analysis made by using the data of the countries taking place within the scope of the study.

Keywords: Economic growth, unemployment, panel data analysis, Okun's law

Jel codes: E24, E32

Scope: Economics

Type: Research

DOI: 10.36543/kauiibfd.2021.040

Cite this Paper: Tunalı Sarı, H. N. (2021). An empirical analysis of the relationship between economic growth and unemployment: case of selected developing countries. KAUJEASF, 12(24), 975-999.

\footnotetext{
${ }^{1}$ This article is based on the author's master's thesis titled 'The Relationship Between Economic Growth and Unemployment in Turkey (2017)". Thesis Information: Bursa Uludag University, Institute of Social Science, Department of Economics, Prof. Dr. Nejla ADANUR AKLAN (Advisor)

${ }^{2}$ It has been declared that the relevant study complies with ethical rules.
} 


\section{İKTISSADİ BÜYÜME VE İŞSIZLLİK ARASINDAKİ İLIŞKİNiN AMPIRIKK ANALİİ: SEÇILMIŞ GELISSMEKTE OLAN ÜLKELER ÖRNEĞİ}

\author{
Hatice Nehrin TUNALI SARI \\ Doktorant - 100/2000 YÖK \\ Doktora Bursiyeri \\ Uludağ Üniversitesi \\ İktisadi ve İdari Bilimler Fakültesi, \\ Bursa, Türkiye \\ ntunali@uludag.edu.tr \\ ORCID ID: 0000-0002-1297-6196
}

Yayına Kabul Tarihi: 02.11.2021

$$
\text { ÖZI Bu çalışmanın temel amacı, }
$$

ekonomik büyüme ve işsizlik arasında uzun dönemli bir ilişki olup olmadığının incelenmesidir. Çalışmada ekonomik açıdan gelişmekte olan ülke statüsünde yer alan Macaristan, Meksika, Polonya, Şili ve Türkiye'nin 2005:Q1-2019:Q1 dönemine ait işsizlik oranı ve Reel Gayri Safi Yurtiçi Hâsıla (RGSYH) makroekonomik göstergelerine ait çeyrek veriler kullanılmıştır. Bu iki değişken arasındaki ilişkinin varlığı panel veri analizi yöntemlerinden faydalanılarak test edilmiştir. Analizlerden elde edilen bulgulara göre, söz konusu dönemde bu ülkelerde işsizlik ve büyüme arasında uzun dönemli bir ilişkinin mevcut olmadığı saptanmıştır.

Anahtar Kelimeler: İktisadi büyüme, işsizlik, panel veri analizi, Okun yasast

JEL Kodu: E24, E32

Alan: İktisat

Türü: Araştırma 


\section{INTRODUCTION}

The most elemental macro-economic magnitude thought to be related to economic growth and effective in the realization of the determined goals is unemployment. The concept of unemployment, which includes not only economic but also many social problems, is one of the major problems that need to be solved for the countries that want to ensure improvement in the welfare level. The unemployment rates having stock qualities exhibit a counterdirectional periodic relationship with the economic growth rate of the country. Therefore, in the shrinkage periods where the rate of economic growth tends to decrease, the unemployment level increases. On the other hand, in the periods where economic expansion occurs, the unemployment level decreases depending on the increase in the growth rate.

Achieving the intended growth goal and ensuring sustainable economic growth is important for the national economies of both developed and developing countries. In recent years, especially in economies of developing countries, even if there is an increase in growth rates, it has been observed that the unemployment rates could not be decreased to the desired levels. In this context, in order to lower the unemployment level to the intended level, it is necessary to determine the factors causing this correctly and support the right policies aiming at the goal of sustainable growth and development. However, because the social, political, economic, demographical, and technological changes and characteristics of the countries differ from each other, so may the policies that support economic growth.

Arthur M. Okun (1962), who researched the relationship between the unemployment rate and economic growth, added a different dimension to the literature with his study. His study revealing the negative relationship between the two variables was criticized and found deficient by some researchers for not including the conjuncture movements occurring in economies enough. However, the relationship the analysis examines can be said to be pioneering many studies after itself, for it is the first with the variables it takes and the analysis it applies.

First, the concept of economic growth, the place of this concept in the literature of economy, and growth theories in the literature of economy were examined in the study. In the second section, the perspectives of different schools of economic thought on unemployment were discussed and the views of different schools were examined. In the third section, the theoretical framework of Okun's Law presented by Arthur M. Okun and the analysis was discussed. The fourth section included, studies examining the relationship between economic growth and unemployment in Turkey and the world. In the last section, the validity of the negative relationship between the unemployment rate and Real Gross Domestic 
Product (GRDP) was tested through econometric analyses by using quarter data of the 2005:Q1-2019:Q1 period of Hungary, Mexico, Poland, Chile, Turkey, which are in the category of economically developing countries.

\section{THE CONCEPT OF ECONOMIC GROWTH AND ITS THEORETICAL FRAMEWORK}

The concept of economic growth is defined as the increase in output per unit of production factors such as labor and capital utilized in production, and/or the positive effects of improvements in the supply of production factors on the potential value of national income (Lipsey, Steiner \& Purvis, 1984, p.732).

It is possible to say that classical economic thoughts' views towards economic growth concept have been shaped from Adam Smith's book Wealth of Nations. Smith, who has developed his analysis on the subject through the concept of capital, specifies the primary elements that affect economic growth as labor productivity, population increase, and capital stock. Smith argues that for realizing the economic growth levels the countries aim, the performance of savings turning into investments needs to be increased first. According to Smith, productivity growth, that is created by the division of labor and composition in producing, and growth created by savings and capital stock form the basic sources of economic growth (Skaggs, 1999, p.482-484). Smith also argues that the developments occurring in the education level of individuals positively affect labor productivity, and this situation brings along economic growth (Smith, 1904, p.784).

It is seen that Keynesian economic thought, which increased its domination with the theses of Classical economy starting to be criticized after the Great Depression ${ }^{3}$, starts from the total demand element in its analyses for economic growth. Keynes argues that the policies countries implement has the power to encourage investments and ensure employment by increasing the total demand. According to Keynes, for the employment level, output, and growth level to reach intended levels, it is necessary to make the right investment decisions and consider the circumstances for the total demand. Each new investment to be carried out through the right economic policies will increase the capital stock and bring the economic growth level forward (Palmerio, 1991, p.20-

\footnotetext{
${ }^{3}$ It is the economic crisis that started in the USA in 1929 and then spread to international markets. The crisis, which is also called the "Great Depression" in the literature, caused the perspective on economic crises to change and the crises to become more debatable. As a result of this crisis, the effects of which spread over a long period of time, it is seen that all economies, especially the USA, suffered a loss. In addition, many organizations that continue to exist today (e.g. International Monetary Fund, International Bank for Reconstruction and Development) were established to eliminate the negative consequences of the related crisis (Iş1k \& Duman, 2012, s. 74-75).
} 
22). Harrod-Domar's growth model, which argues for a dynamic growth analysis from Keynes's perspective, puts forward that capital stock will increase through investments and savings. Depending on this situation, output, production, and growth level will increase. According to the model, the output level in the economy is directly connected to the capital stock, and countries wanting to achieve a certain economic growth should determine policies that will affect the capital stock positively. In the model, there is a negative relationship between growth and capital/output ratio ${ }^{4}$ and a positive relationship between savings and growth rate (Coombs, Saviotti \& Walsh, 1987, p.139-140).

The Neoclassical economic theory, on the other hand, argues that depending on the circumstances it is in, each country experiences two different growing experiences basically. According to the first one of these, in the first stages of the growth process, the capital stock needs to be expanded faster when compared to labor to ensure economic development. In this process, there will be more capital per labor, which will affect labor productivity positively. Consequently, the output level of the labor will be higher than at the beginning. However, it is quite difficult for this situation to continue in the long run. Because after a while, the decreasing productivity becomes involved, and due to this situation, profits decrease with the return of the capital starting to decrease. At the end of the process, on the other hand, it will come to the steady-state balance where net profit is zeroized and capital stock rates are decreased. On the other hand, in the steady-state balance that is considered as the second state, the economy has to renew itself. For this case to actualize, besides steadily maintaining the current circumstances of the economy, technological shocks also need to be supplied (Yeldan, 2009, p.113-114). Another element Neoclassical growth theory emphasizes is savings. Accordingly, the capital stock of countries with higher saving rates will grow in a more balanced way, and there will be an increase in the output levels. Therefore, countries with low savings need to increase their savings in order to achieve the growth level they aim for. Also, in the Neoclassical growth model, elements such as human capital, technology, population, and R\&D (research and development) are regarded as external (Zhang, 2005, p.417).

In endogenous growth models that are considered to have emerged as a result of the studies of economists like Arrow (1962), Romer (1986), Lucas (1988), and Barro (1990), concepts such as education, health, technological developments, $R \& D^{5}$, income distribution, human capital, etc. are included in the

\footnotetext{
${ }^{4}$ In the model, it is obtained by comparing the amount of output and the level of capital.

${ }^{5}$ R\&D: Research and Development
} 
model as endogenous elements, unlike the previous studies. It is seen that endogenous growth models mainly focus on the concept of technological development and use technology as the basic variable. Accordingly, developments occurring in technology postpone the decreasing productivity in time; gainings increase as the term extensions occur, and as a result, economic growth level makes progress (Szostak, 2009, p.62-66). Also, according to endogenous growth models, capital stock in the economy is not only subject to physical discriminations but also discriminations such as human, social capital, etc. In the models in question, saving is taken as a variable that is determined as a result of the decisions of the household and directly transferred to investments.

Post-Keynesian economic thought argues that economic growth is a historical process and that examining it in the long term will give more accurate results. According to post-Keynesian thought, developments occurring in technology and changes in returns to scale are internal factors and cause significant effects on economic growth. In the analysis, the total demand factor has an important place, and the concept of income was approached by dividing it into two as the worker and capitalist incomes (Kaldor, 1957, p. 596-614).

Marxian economic thought has created a time-based analysis of the concept of economic growth. Accordingly, in the process of economic growth, it is very important from which phase societies start growing and by going forward to which phase they will end the process. According to the Marxian growth model, all societies will be involved in the growth process, show change, and by reaching the level of communist society from the level of primitive society, end the growth process. In economies that have come to the last stage, on the other hand, problems such as unemployment, poverty, etc. will completely disappear, everyone will contribute to the national income by involving in the economic system within the scope of their skills and take their share from this income within the context of their needs (Harrison, 1996, p.70-71)

\section{THE CONCEPT OF UNEMPLOYMENT AND ITS PLACE IN THE ECONOMIC THEORY}

Unemployment is defined as the total of individuals in a country who are above a certain age and ready to work but unable to find jobs under the current circumstances. An economy experiencing the unemployment problem needs to determine the reasons for this situation correctly and analyze the economic magnitudes that the said concept is in connection with unambivalently. For this reason, it is seen that the concept of unemployment is frequently discussed in the economic literature especially in the context of the labor market.

It is possible to see the opinions of Classical Economy Theory, which argues that all markets, including labor, would be equalized in the economic 
system, on the concept first in the studies of Adam Smith. Smith argues that the cost of labor is determined by labor demand and that this demand differs according to the state of scarcity or wealth the economy is in. According to Smith, sources spared for labor decrease compared to the previous period, especially in periods of shortage, and by increasing the competition between the workers, this decrease results in unemployment. However, this situation would not be lasting according to Smith. The decrease in the labor demand will cause income levels to decrease after a while and the increasing poverty will cause the labor demand to decrease by bringing about social problems (epidemics, etc.). The decrease in labor demand, on the other hand, will result in poverty going back to its former level by balancing both the cost of labor and the market (Smith, 1904, p.100-104). Another element Smith lays stress upon about labor demand is the developments occurring in the production process. Smith argues that developments happening in the tools used throughout the production process will increase unemployment by negatively affecting the labor demand. However, according to Smith, this situation is temporary as well. Because, after a while, the elements taking the production process forward will increase the gain of the employer by positively affecting productivity, and this situation will cause the labor demand to increase and the unemployment level to return to its former level (Smith, 1904, p. 104105). Another Classical Economist who dwells upon the concept of unemployment is Ricardo. According to Ricardo, the element that will change the existing unemployment rate in the economy is the investor's form of utilizing the profit they gained. Similar to Smith, Ricardo also argued that the developments occurring in the production process would increase the gain of the investor but decrease the labor demand. For this situation to be removed, the said profits need to be directed to the employment of labor (Ricardo, 1821, p.288291).

The fact of unemployment, which became an ongoing problem in the crisis period that emerged with the Great Depression, is also discussed in Keynes's work named The General Theory of Employment, Interest and Money, published in 1936. According to Keynes, changes in the labor quantity supplied in the labor market are effective on nominal wage levels, and this situation, on the other hand, prevents the labor supply and demand balancing and creating a stable equilibrium in the market. Keynes also argues that a balance to occur in the labor market would not be continuous and states that nominal wages being downwardly rigid is the reason for this (Keynes, 2018, p. 161-169).

It is possible to see the opinions of the Neoclassical school on unemployment in Modigliani's (1994) analysis. In his study, Modigliani dwelled on the differences between Keynesian economy and Classical economy and 
started from concepts such as liquidity preference, money income balance, goods market equilibrium, production, investment, and saving. According to Modigliani, the fact that the marginal product value of the labor is lower than the wage level in the market negatively affects production and employment levels. This situation results in the unemployment level increasing. Modigliani also argues that unemployment to return to its former level can be possible with the balance of marginal product value of the labor and wage level in the market (Modigliani, 1944, p.46-48). Another economist who gives place to opinions about employment within the framework of the Neoclassical economy is Patinkin (1948). Patinkin who lay stress on the concept of price flexibility in the study he conducted, argues that the economy will go towards full employment in the case of accepting price flexibility for each market, and thus, Keynes's theory of underemployment will become inquirable (Patinkin, 1948, p.559-563).

The opinions of the Monetarist economic school that emerged as a response to Keynesian and Neoclassical economic school on unemployment can be interpreted from the analysis Friedman did. Friedman argues that each economy has a balance production level that reflects its potential, that this production level can be described as the normal level in the economy, but even at this level, unemployment can emerge. Even if this rate that is described as the natural rate of unemployment by Friedman is eliminated with monetary policies implemented in the short term under adaptive expectations, it can re-emerge in a different equilibrium point in the labor market in the long term. Friedman describes the concept of natural unemployment as a situation that exists in every circumstance and is mainly determined by real elements (Friedman, 1977, p.454459).

The New Classical economic theory, where expectations are considered rational, has based its analyses of unemployment on the concept of rationality. According to the New Classical school of economic thought, which regards the occurring unemployment level as the natural unemployment level, under the existence of economic units with rational expectations, policies to be carried out in problems such as unemployment, etc., will not bring results. Another subject the new classical economic theory lays stress upon is the choices the workers make in their free time and in between work. Accordingly, in cases where real wage expectations are higher than the current period wage levels because workers increase their free time preferences with the expectation that the wage levels will increase in the next period, unemployment increases as well. For New Classics, in changes occurring in real wages, labor demand reacts simultaneously. Therefore, in theory, changes emerging in employment levels and unemployment 
rates are a result of the decisions the labor makes under rational expectations (Lucas \& Rapping, 1969, p.723-727).

Real Business-Cycle theory that accepts the same hypotheses as New Classic economic thought concerning the main elements has achieved different results about unemployment and employment by including technology into the analysis. Real Business-Cycle theory argues that the main factors effective on unemployment level and employment are changes in technology and effects these changes have on productivity. Accordingly, due to the technological shocks occurring in the economy, productivity in production increases, and depending on this situation, workers form rational expectations for the changes that may occur in wages due to the productivity growth. When workers consider the said technological shock as temporary, by directing their free time preferences to the future, they tend to offer more labor in the first periods where the technological shock occurs intending to prefer the free time in the future. Therefore, according to the Real Business-Cycle theory, while employment level increases according to productivity growth and expectations of labor, the unemployment rate tends to decrease (Gali, 1999, p.253-261).

Opinions of the New Keynesian economic theory, which aims to develop the thesis of Keynesian economic thought and completing the aspects in the theory that are described as deficiencies, about the concepts of unemployment and employment are formed within the framework of nominal and real rigidity (Gordon, 1990, p.1115). The New Keynesian economic school, which uses the non-accelerating inflation rate of unemployment (NAIRU) instead of the natural unemployment concept that has a significant place in the analyses of the Monetarist economic school did on labor, has created a new analysis for unemployment by considering imperfect competition factors as data. Accordingly, NAIRU is considered as a concept that can be explained with the changes occurring in unemployment rates between periods, provides insight about the measure of unemployment resulting from business cycles, and reflects the power of the labor market (Rodenburg, 2007, p.2-18).

Post-Keynesian economic thought defines the capitalist system as a monetary economy operating based on uncertainty and makes a connection between the concepts of employment and capitalism (Davidson, 1994, p.88). According to Post Keynesians, the capitalist system surrounded by uncertainty is always inclined to be unsteady. For this reason, it includes all elements that would bring out unemployment within its functioning. Therefore, unemployment can emerge in the economy without the need for any external factors (Forstater, 2001, p.6-9). Post-Keynesian economic thought argues that directing monetary and fiscal policies in a way that would ignore the employment and growth levels to 
achieve goals such as price stability, etc. will cause serious economic consequences in the long term (Tcherneva \& Wray, 2005, p.3-4). According to Post Keynesians, the fact that macroeconomic magnitudes deviate from stability and state interventions are not adequate can turn into a long-term problem. Therefore, in certain periods, states need to be integrated into the economic system as the last interventionist power and by employment-increasing policies, reduce unemployment (Wray, 2007, p.7-11).

Opinions of socialism on unemployment are generally formed around the concept defined as industrial reserve army ${ }^{6}$ in Karl Marx's analysis. According to Marx, in case of increased capital levels in the economy, labor extends as well; however, the said extension occurs at a gradually decreasing rate. Marx argues that along with the population increases, labor demand will increase as well. Therefore, in order to employ both the existing labor and the new labor emerging with the population growth and prevent unemployment, capital stock needs to increase continuously. According to Marx, if the capital stock and labor demanded by the capitalist are not directly proportional, the unemployment problem emerges in the economic system. Marx argues that in order to solve the problem of unemployment, there should not be new employment areas formed within the system, and the unemployed labor named industrial reserve army should continuously be moved to these areas (Marx, 1867/2012, p.608-613).

\section{THEORETICAL FRAMEWORK: OKUN'S LAW}

In his work, titled Potential GNP: Its Measurement And Significance, published in 1962, Arthur M. Okun researched the relationship between economic growth and unemployment rate based on USA data between 1947 and 1960. What lies at the basis of the said relationship named Okun's Law in the literature is that high growth levels reduce unemployment and low growth rates increase unemployment (Okun, 1962, p.89-92). According to Okun, one of the most important economic goals of a country is to ensure employment. On the other hand, the realization of the said goal is directly related to the output production potential of the country. Okun argues that the potential output level of a country can be measured with not an infinite total demand but the quantity of labor employed. Intending to prove the results he obtained in his analysis, Okun used 3 different methods being test gaps, first differences, and suitable trend and flexibility (Okun, 1962, p.90).

- Test Gaps: In this method, Okun tested by selecting periodic exponential paths of potential product quantity. Throughout the selection and test process, different

\footnotetext{
${ }^{6}$ With the development of industrialization, labor that cannot find a job despite the desire to work is defined as the "industrial reserve army" by Karl Marx.
} 
growth rate comparison levels were made use of. In the regression equation, a connection was formed between unemployment rates and the percent values of the deviations of the potential output stated as exponential paths. Okun determined that the model that he created considering different exponential paths and different periods vary between the values 0,28 and $0,38 . \mathrm{U}$ being the unemployment rate, the equation is:

$$
\mathrm{U}=3,72+0,36 \text { (output gap }{ }^{7} \text { ) }
$$

. Accordingly, if the deviation in the potential output is less than 1 , the unemployment occurs at the level of 3,72 (Okun, 1962, p.92).

- First differences: A relationship was formed between real output level and unemployment rate through the regression equation estimated from the quarterperiod data of 55 observations between 1947:Q2-1960:Q4. The result obtained by Okun is as in formula 2.

$$
\mathrm{Y}=0,30+(-0,30) \mathrm{X}
$$

According to the regression equation in formula 2, a significant relationship was found between the percentage expression of the change of three months occurring in the unemployment rate $(\mathrm{Y})$ and the percentage expression of the change of three months occurring in the real output (X). Accordingly, the increase of $1 \%$ that emerged in the output causes a decrease of $0,3 \%$ points in the unemployment rate (Okun, 1962, p.91).

- Suitable Trend and Elasticity: While the first one of the methods mentioned above grounds the hypotheses that the unemployment rate is stable at a certain level and potential output is open, the second method is based on the changes occurring in output and unemployment rates. In this method, on the other hand, Okun argues that the hypothesis that a trend can be formed for output growth at the stable unemployment level can be ignored, and even without a trend, coefficients of unemployment and output can be obtained. The equation obtained by Okun as a result of the calculations done on the method is as follows:

$$
\log N_{t}=\log N_{f} / P_{0}^{\alpha}+\log A_{t}-\alpha r t^{8}
$$

According to the equation in formula 3 , the logarithm of the employment level appears in connection with the time trend and the logarithm of the actual output. It is seen that as a result of implementing the said equation in different periods, the coefficient of elasticity varied between 0,35 and 0,40 . Accordingly,

\footnotetext{
${ }^{7}$ Output Gap $=$ Actual Output-Potential Output

${ }^{8}$ In the equation, $A$ is the actual output, $P$ is the potential output, $N_{f}$ is the potential employment level, $\mathrm{r}$ is the constant growth rate of the potential output, $\mathrm{t}$ is time, and $N$ is employment. For detailed information, see, Okun, Ibid, p.89-93.
} 
it was determined that each decrease of $1 \%$ emerging in the unemployment level caused an increase of less than $3 \%$ rate.

When Okun added the data belonging to the period he examined to the equation he obtained, he reached the result of:

$$
\mathrm{P}=\mathrm{A}\{1+0,32(\mathrm{U}-4)\}
$$

The equation states that if the unemployment rate is at the level of $4 \%$, the potential output will be equal to the actual output (Okun, 1962, p.91).

the said profits need to be directed to the employment of labor (Ricardo, 1821, p.288-291).

\section{LITERATURE REVIEW}

When the studies researching the relationship between economic growth and unemployment were examined, it was observed that many analyses were referred to and different results were reached. It is seen that some of these studies calculated Okun's coefficient for the country or country group they examined while some, on the other hand, gravitated toward determining the relationship between economic growth and unemployment. In this direction, the results obtained from studies conducted in Turkey and the world were briefly included in this part of the study.

Friedman and Wachter (1974) tested Okun's law in their study they conducted by using the quarter data of the period of 1954:Q1-1970:Q4 from the real output and unemployment data. Accordingly, the relationship between the variables emerged as negative in the short term, and it was determined that changes occurring in the real output had a greater effect on the unemployment level.

From the data of the USA between the years 1950 and 1985, Evans (1989) examined the relationship between economic growth and unemployment. According to the analysis result, it was observed that the two variables had a strong negative relationship according to the VAR (vector autoregressive model) analysis, and had a two-way causality characteristic according to the Granger causality analysis.

In his study conducted for the economy of the USA, Prachowny (1993) tested the relationship between the unemployment gap and output gap and determined that there was a negative relationship between the variables. Prachowny criticized describing Okun's Law as a negative relationship only between two variables and argued that in order for the analysis to result right, variables such as labor force participation rate, work hours, and labor efficiency need to be included in the model. 
Weber (1995) researched the relationship between variables from the data of periodic GNP and periodic unemployment during World War Two in the USA. Weber, who used both static and dynamic models throughout the analysis, detected Okun's coefficient for the said period as -0.25 and determined that the increases that emerged in the growth rate had a reducing effect on unemployment. Also according to Weber, in said times, in periods where supply shocks occurred, the relationship between growth and unemployment had similar characteristics.

Using regional and national data from the USA between 1959-1998, Freeman (2000) attempted to determine Okun's coefficient level for the said regions in his study. Freeman, who determined as a result of the analysis he conducted that Okun's coefficient varied between 1.8 and 3.6 for the regions considered, concluded that there was no statistically significant difference between the regions.

Harris and Silverstone (2000) researched Okun's coefficient for New Zealand. The researchers, who started from the cointegration analysis, determined in the said analysis that the direction of the relationship was only from real GDP towards unemployment. Another study conducted by Harris and Silverstone (2001), researched the relationship between economic growth and unemployment for the seven OECD countries (Germany, America, Australia, United Kingdom, Japan, Canada, and New Zealand). The result of the analysis conducted was found that there was not a long-term relationship between unemployment and GDP.

Viren (2001), in his study based on the data between 1960-1997 for OECD countries, found that the economic growth level had a decreasing effect on unemployment when it is higher than the long-term average growth level. Another result of the study is that it takes an average of three years for the shocks in the unemployment rate to balance for these countries, and the shocks in the population ratio increase the unemployment rate.

On the other hand, Izyumov and Vahaly (2002) researched the relationship between the validity of Okun's coefficient and GDP and unemployment for transition economies. While the 25 countries examined in the study consist of 10 European Union (EU) member countries named reform leaders, the remaining 15 countries consist of countries out of the EU. According to the results of the study, while Okun's Law emerged in transition economies that became EU members in the late period, such a relationship was not found valid in non-candidate countries.

Christopoulos (2004) researched the relationship between output level and the unemployment rate for Greece based on the data for the period 19711993. In the analysis, Christopoulos, who examined Greece by dividing it into 
regions and applied panel data analysis, found that the unemployment rate and output level move together in 6 of the 13 regions and that the relationship between the variables is valid only in the long term for all regions.

In the study they analyzed the validity of Okun's Law for South Africa based on unemployment and economic growth data between the years 1970 and 2005. Marinkov and Geldenhuys (2007) revealed that there is a reverse relationship between the unemployment rate and output level. The conclusion of the analysis was that an increase of $1 \%$ in the output gap reduced periodic unemployment between the rates of $0.16 \%$ and $0.77 \%$. It was also found in the study that after years of structural break, the unemployment level responds to changes occurring in the economic growth rate more.

Barışı et al. (2010) tested the relationship between unemployment and economic growth for Turkey, based on the data for the years 1988-2008. In the study, the situation of the relationship between these variables in the periods of expansion-recession was researched and the Markov Regime Change Model was used. Accordingly, while the increases in the growth level reduce unemployment when the economy is in the recession period, no statistically significant relationship was found between unemployment and growth in the expansion periods.

Mihç1 and Atılgan (2010) researched the validity of Okun's Law for Turkey through the Hodrick-Presscott filter in the study they conducted by using unemployment and economic growth data between the years 1970 and 2006. The conclusion of the analysis was that the increases in economic growth did not reduce unemployment in the said period significantly, and it was argued that the concept of jobless growth was valid for Turkey.

Tar1 and Abasiz (2010) studied the changes in Okun's coefficient for the periods of cyclical fluctuations, taking into account the contraction and expansion periods of the economy, based on the unemployment and growth data of Turkey between 1968 and 2008. In the study, it was observed that the fluctuations occurring in the growth rates during recession periods affect unemployment more than the fluctuations that occur during the expansion periods.

Binet and Facchini (2013) analyzed the relationship between unemployment and growth for 22 regions of France, based on the data between the years 1990 and 2008. In the study, in which panel data analysis was used as a method, the existence of the relationship was determined for 14 regions, while insignificant results were obtained for 8 regions. According to the authors, based on the results obtained, the growth policies to be implemented should vary from region to region. 
Özdemir and Yıldırım (2013) examined the relationship between economic growth and employment by using monthly data of Turkey of the period between 2005 and 2013. In the study, the self-extracted wavelet approach was used and it was determined that there is one-way causality from economic growth to employment. It was also observed that the causal relationship between the variables disappears in the long run.

Altunöz (2015), in his study investigating the validity of Okun's law for Turkey, based on unemployment and real growth data, discussed the period of 2000:Q1- 2014:Q1. In the study where Granger causality analysis was applied, it was concluded that there was no relationship of causality between variables.

Turan (2015) examined the cointegration relationship between unemployment and growth using the ARDL bounds test approach, based on the quarterly data for the Turkish economy between the years 1962:Q1 and 2014:Q3. According to the bounds test results, it was concluded that there was no cointegration relationship between the variables for the period in question.

Ar1 (2016) researched the relationship between economic growth and unemployment based on the data of Turkey between the years 1980 and 2014. As a result of the analysis, it was concluded that there was no significant relationship between variables in both the short and long term. The researcher interprets this situation as that the phenomenon of growth without employment is valid in Turkey for the period in question.

Mucuk et al. (2017) analyzed the validity of Okun's Law for Turkey based on the unemployment and growth data for the years 2002-2014. As a result of the impulse-response analysis, it was determined that shocks occurring in growth rates negatively affect unemployment, while shocks at the unemployment level have a positive effect on growth. According to the results of another analysis (Johansen Cointegration Test) included in the study, no significant relationship was found between variables in the long run.

Soylu et al. (2018) tested the validity of Okun's Law in their study, in which they took into consideration the data between 1992 and 2014 for Eastern European countries (Belarus, Bulgaria, Czech Republic, Romania, Poland, Ukraine, Hungary, and Slovakia). According to the results obtained as a result of the panel data analysis, the significance of the model is high and the relationship between growth and unemployment is found to be high, negative, and significant.

There are many studies in the literature examining the relationship between economic growth and unemployment. However, it is seen that the relationship between the two variables is studied less in developing countries. For this reason, the study in question investigated the relationship between 
unemployment and growth rates in the context of countries that have the characteristics of developing countries and are also members of the OECD.

\section{EMPIRICAL METHOD AND THE DATA SET}

In the study based on panel data analysis, the relationship between RGDP and unemployment rate (UR) between the periods 2005: Q1-2019: Q1 of Hungary, Mexico, Poland, Chile, Turkey, which are developing and also OECDmember countries, is researched. The countries covered were determined by considering the countries that were classified as developing countries and members of the OECD (Organisation for Economic Co-operation and Development) in the relevant period. The seasonally adjusted values of the data were obtained from the OECD database.

According to the panel data analysis, a simple regression equation is estimated as follows:

$$
Y_{i t}=\alpha_{i}+\beta X_{i t}+u_{i t}{ }^{9}
$$

In the equation, $\mathrm{i}(\mathrm{i}=1,2, \ldots \ldots, \mathrm{N})$ is the sections and $\mathrm{t}(\mathrm{t}=1,2, \ldots ., \mathrm{T})$ is the time interval. In studies based on panel data analysis, in order to determine the model to be applied to determine the relationship between the series, it is necessary to investigate the stationarity conditions of the series first. When the related methodology is examined, it is seen that the unit root tests to be made to determine the stationarity are divided into two as first generation and second generation. In order to decide which of these unit root tests to choose, the situation that reveals the dependency relationship between the units and which is expressed as cross-section dependence in the literature should be tested. In the literature, it is seen that the Breusch-Pagan Lagrange Multiplier (LM) (1980) test, Pesaran CD (2004), and $L M_{a d j}(2008)$ tests are commonly used to investigate the presence of cross-section dependence. However, studies show that Peseran CD (2004) and $L M_{\text {ad } j}$ (2008) cross-section dependency tests give more successful results than the LM (1980) test. In the analysis, cross-section dependency was investigated for both variables, based on Peseran CD (2004) and $L M_{a d j}$ (2008) tests.

Peseran CD (2004) test statistic is as follows:

$$
\mathrm{CD}=\sqrt{\frac{2 T}{N(N-1)}}\left(\sum_{i=1}^{N-1} \sum_{j=i+1}^{N} \hat{\rho}_{i j}\right)
$$

$L M_{a d j}(2008)$ test statistic is as follows;

$$
L M_{a d j}=\sqrt{\frac{2}{N(N-1)}} \sum_{i=1}^{N-1} \sum_{j=i+1}^{N} \frac{(T-k) \hat{\rho}_{i j}^{2}-\mu_{T i j}}{v_{T i j}}
$$

${ }^{9} U E P_{i t}=\alpha_{i}+\beta R G D P_{i t}+u_{i t}$ 
Both tests accept that there is no cross-sectional dependence on the basic hypothesis $\left(H_{0}\right)^{10}$. The Peseran CD (2004) test shows a standard normal distribution and is based on the sum of the correlation coefficients between the horizontal sections. In the $L M_{a d j}$ equation, $\mu_{T i j}$ is the average, and $v_{T i j}$ is the variance.

Table 1: Cross-Section Dependence Test Results

\begin{tabular}{|l|c|c|c|c|}
\hline \multicolumn{3}{|c|}{ Ineseran CD Test (2004) } & \multicolumn{2}{c|}{ Intercept \& Trend } \\
\hline Variables & Test Statics & P-Value & Test Statics & P-Value \\
\hline RGDP & -5.500 & $0.000^{*}$ & -5.597 & $0.000^{*}$ \\
\hline UR & -3.157 & $0.000^{*}$ & -3.011 & $0.000^{*}$ \\
\hline LM $_{\text {ad j Test (2008) }}$ & \multicolumn{3}{|c|}{ Intercept \& Trend } \\
\hline \multicolumn{5}{|c|}{ Intercept } \\
\hline Variables & Test Statics & P-Value & Test Statics & P-Value \\
\hline RGDP & 10.555 & $0.000^{*}$ & 11.210 & $0.000^{*}$ \\
\hline UR & 17.368 & $0.000^{*}$ & 30.307 & $0.000^{*}$ \\
\hline
\end{tabular}

, Indicates significance at the $1 \%$ level

Table 1 contains the results of the cross-section dependency test of RGDP growth rate and unemployment rate variables. According to these statistical results, the main hypothesis $\left(H_{0}\right)$ showing that there is no cross-section dependency in both fixed and fixed and trend models is rejected for $1 \%, 5 \%$, and $10 \%$ significance levels. This situation shows that there is cross-section dependence for both variables. The results obtained indicate that the second generation unit root tests, which take into account the presence of cross-section dependence, should be moved to. The main second generation unit root tests can be listed as MADF (Taylor and Sarno, 1998), SURADF (Breuer, et al., 2002), PANIC (Bai and Ng, 2004), CADF (Pesaran, 2007), and New PANIC (Bai and $\mathrm{Ng}, 2010)$. To be able to decide clearly, which of the unit root tests to choose, the assumption of homogeneity should be tested.

The homogeneity test is tested through the delta test developed by Pesaran and Yamagata (2008). In the test where the basic hypothesis

\footnotetext{
${ }^{10} \mathrm{H} 0=\operatorname{Cov}(\mathrm{itjt})=0 \quad \mathrm{i} \neq \mathrm{j}$, $\mathrm{H} 1=\operatorname{Cov}(\mathrm{itj} t) \neq 0 \quad \mathrm{i} \neq \mathrm{j}$.
} 
$\left(H_{0}\right)^{11}$ accepts the homogeneity of the slope coefficients, the $\operatorname{delta}(\tilde{\Delta})$ and the corrected delta $\left(\tilde{\Delta}_{a d j}\right)$ test statistics are given together.

Table 2: Homogeneity Test Results

\begin{tabular}{|c|c|c|c|c|}
\hline \multicolumn{5}{|c|}{ Pesaran \& Yamagata (2008) } \\
\hline \multicolumn{3}{|c|}{$\tilde{\Delta}$} & \multicolumn{2}{|c|}{$\tilde{\Delta}_{a d j}$} \\
\hline Variables & Test Statics & P-Value & Test Statics & P-Value \\
\hline RGDP & -1.105 & 0.865 & -1.135 & 0.872 \\
\hline UR & 0.767 & 0.222 & 0.788 & 0.215 \\
\hline
\end{tabular}

Table 2 shows the homogeneity test results of the RGDP growth rate and unemployment rate. Accordingly, it is seen that the $H_{0}$ basic hypothesis, which accepts homogeneity for both variables, cannot be rejected at significance levels of $1 \%, 5 \%$, and $10 \%$.

In the analysis based on the cross-section dependence and homogeneity test results, the stationarity of the series was studied by the New PANIC (Bai and $\mathrm{Ng}, 2010$ ) test, which was developed based on the PANIC (Bai and Ng, 2004) test. Bai and $\mathrm{Ng}$ unit root analysis includes (balanced) panels consisting of $\mathrm{T}$ number of time series and $\mathrm{N}$ number of cross-section units, considering the relationship between cross-section ends (Barbieri, 2009, p.33).

Table 3: New PANIC (Bai ve Ng, 2010) Unit Root Test Results (RGDP)

\begin{tabular}{|c|c|c|c|c|}
\hline \multicolumn{5}{|l|}{ RGDP } \\
\hline \multicolumn{5}{|l|}{ Level } \\
\hline \multicolumn{3}{|c|}{ Intercept } & \multicolumn{2}{|c|}{ Intercept \& Trend } \\
\hline & Test Statics & P-Value & Test Statics & P-Value \\
\hline$P_{a}$ & -0.776 & 0.217 & -0.779 & 0.218 \\
\hline$P_{b}$ & -0.698 & 0.242 & -0.698 & 0.242 \\
\hline PMSB & -0.499 & 0.308 & -0.499 & 0.308 \\
\hline \multicolumn{5}{|c|}{ 1. Difference } \\
\hline \multicolumn{3}{|c|}{ Intercept } & \multicolumn{2}{|c|}{ Intercept \& Trend } \\
\hline & Test Statics & P-Value & Test Statics & P-Value \\
\hline$P_{a}$ & -23.348 & $0.000^{*}$ & -23.348 & $0.000^{*}$ \\
\hline$P_{b}$ & -8.782 & $0.000^{*}$ & -8.783 & $0.000^{*}$ \\
\hline PMSB & -2.155 & $0.014^{* *}$ & -2.152 & $0.016^{* *}$ \\
\hline
\end{tabular}

${ }^{*},{ }^{* *}$, Indicates significance at the $1 \%$ and $\% 5$ level.

${ }^{11} \mathrm{H} 0: 1=2=\ldots=\mathrm{n}($ for each $\mathrm{i})$

$\mathrm{H} 1: 1=2=\ldots \neq \mathrm{n}$ (for at least one $i$ ) 
KAUJEASF 12(24), 2021: 975-999

Table 4: New PANIC (Bai ve Ng, 2010) Unit Root Test Results (UR)

\begin{tabular}{|c|c|c|c|c|}
\hline \multicolumn{5}{|l|}{ Level } \\
\hline \multicolumn{3}{|c|}{ Intercept } & \multicolumn{2}{|c|}{ Intercept \& Trend } \\
\hline & Test Statics & P-Value & Test Statics & P-Value \\
\hline$P_{a}$ & 0.333 & 0.630 & 0.334 & 0.631 \\
\hline$P_{b}$ & 0.373 & 0.645 & 0.374 & 0.646 \\
\hline PMSB & 0.609 & 0.728 & 0.610 & 0.729 \\
\hline \multicolumn{5}{|c|}{ 1. Difference } \\
\hline \multicolumn{3}{|c|}{ Intercept } & \multicolumn{2}{|c|}{ Intercept \& Trend } \\
\hline & Test Statics & P-Value & Test Statics & P-Value \\
\hline$P_{a}$ & -8.128 & $0.000^{*}$ & -8.128 & $0.000^{*}$ \\
\hline$P_{b}$ & -4.271 & $0.000^{*}$ & -4.270 & $0.000^{*}$ \\
\hline PMSB & -1.817 & $0.034^{* *}$ & -1.816 & $0.035^{* *}$ \\
\hline
\end{tabular}

*,*, Indicates significance at the $1 \%$ and $\% 5$ level.

In Tables 3 and 4, unit root test results of RGDP and unemployment variables are seen. Accordingly, it is seen that in the level values of both series, the obtained test statistics values accept the $H_{0}$ hypothesis, which accepts the presence of unit root at significance levels $1 \%, 5 \%$, and $10 \%$. Therefore, the unit root test was applied again by taking the first differences of the series. As a result of the test, stability was achieved at $1 \%$ and $5 \%$ significance levels of the test statistics values of both series. The fact that both series are stationary at their 1st difference leads the I(1) analysis to research the presence of a cointegration relationship between the series.

In linear combinations of series with unit roots at level values, the presence of unit root may disappear and a long-term relationship may arise. The determination of the said long-term relationship is possible with cointegration tests. Like panel unit root tests, panel cointegration tests also divide into two based on cross-sectional dependence. Therefore, for the accurate determination of the panel cointegration test, the cross-sectional dependence and homogeneity of the model should be analyzed.

Table 5: Cross-Section Dependence Test Results of the Model

\begin{tabular}{|l|c|c|}
\hline & Test Statics & P-Value \\
\hline Cd (Peseran, 2004) & 8.830 & $0.000^{*}$ \\
\hline Lm Adj. & 31.656 & $0.000^{*}$ \\
\hline
\end{tabular}

${ }^{*},{ }^{* *}$, Indicates significance at the $1 \%$ and $\% 5$ level.

Table 6: Homogeneity Test Results of the Model 


\begin{tabular}{|c|c|c|}
\hline & Test Statics & P-Value \\
\hline$\tilde{\Delta}$ & 6.112 & $0.000^{*}$ \\
\hline$\tilde{\Delta}_{\boldsymbol{a d j}}$ & 6.276 & $0.000^{*}$ \\
\hline
\end{tabular}

*, Indicates significance at the $1 \%$ level.

Table 5 shows the cross-section dependence of the model, and Table 6 shows the homogeneity test results. Accordingly, the basic hypothesis $\left(H_{0}\right)$ that accepts no-cross-sectional dependence and the basic hypothesis $\left(H_{0}\right)$ that accepts the homogeneity assumptions are rejected for $1 \%, 5 \%$, and $10 \%$ significance levels. Hence the model is cross-section dependent and heterogeneous. The obtained results show that panel cointegration tests that take into account the presence of cross-sectional dependency should be selected. Commonly used ones of these cointegration tests that are considered as the second generation in the literature, can be listed as Panel Variance Ratio (Westerlund, 2005), Panel ECM (Westerlund, 2007), and Panel-DH (Westerlund, 2008). In the study, the presence of a cointegration relationship between the series was investigated through the Panel ECM test, since it is the second generation, does not ignore heterogeneity, and takes into account the I (1) states of both dependent and independent variables.

In Westerlund's analysis, the existence of the cointegration relationship is examined through four different tests based on the error correction model. In these tests, the significance of the error term and whether it has a negative value is investigated (Westerlund, 2007, p.715-721).

Table 7: Westerlund (2007) Panel Cointegration (Panel ECM) Test Results

\begin{tabular}{|c|c|c|c|}
\hline \multicolumn{4}{|l|}{ Intercept } \\
\hline & & asym & bootstrap \\
\hline & Test Statics & P-Value & P-Value \\
\hline g_tau & 1.432 & 0.924 & 0.898 \\
\hline g_alpha & 1.691 & 0.955 & 0.954 \\
\hline p_tau & 0.046 & 0.518 & 0.638 \\
\hline p_alpha & 0.418 & 0.662 & 0.665 \\
\hline \multicolumn{4}{|c|}{$\begin{array}{l}\text { Intercept and Trend } \\
\text { Sabitli ve Trendli Model }\end{array}$} \\
\hline & & asym & Bootstrap \\
\hline & Test Statics & P-Value & P-Value \\
\hline g_tau & 1.811 & 0.965 & 0.949 \\
\hline g_alpha & 1.897 & 0.971 & 0.983 \\
\hline
\end{tabular}


KAUJEASF 12(24), 2021: 975-999

\begin{tabular}{|l|c|c|c|}
\hline p_tau & -0.939 & 0.174 & 0.399 \\
\hline p_alpha & 0.615 & 0.731 & 0.745 \\
\hline
\end{tabular}

In the panel ECM (Westerlund, 2007) cointegration test, cross-section dependence, and homogeneity/heterogeneity assumption are considered while evaluating the statistical results obtained. Accordingly, interpretation is made according to the results of g_tau and g_alpha group test statistics under the assumption of heterogeneity, and according to the results of $p_{-}$tau and $p \_a l p h a$ panel test statistics under the assumption of homogeneity. In addition, it is recommended to interpret the calculated values using the bootstrap process in order to prevent misleading results that may occur due to cross-section dependence (Westerlund, 2007, p.720-724). As a result of the tests conducted, it was determined that the model has cross-section dependence and shows heterogeneous characteristics. Therefore, the results of $g \_$tau and $g \_$alpha test statistics will be interpreted based on bootstrap probability values. As can be seen, the $H_{0}$ basic hypothesis, which accepts that there is no cointegration relationship, is accepted according to the significance levels of $1 \%, 5 \%$, and $10 \%$, according to the results of the test statistics in both the fixed and the fixed and trend models.

As a result, according to the statistical data in Table 7, it was determined that there is no long-term cointegration relationship between the unemployment rate and RGDP variables for the countries within the scope of the study.

\section{CONCLUSION}

In the literature, it is seen that there are many studies examining the relationship between economic growth and unemployment rates from different perspectives. Expectations for the unemployment problem, which is thought to arise as a result of the deterioration in the economic dynamics of countries, are that at the beginning, the labor market will automatically stabilize and unemployment rates will start to decrease. However, over time, it is understood that it will not be possible to eliminate the said problem completely and it is very difficult to provide continuous employment.

According to economic theory, with the increase in the economic growth rate of a country, the employment level increases as well, and thus unemployment level decreases. However, the results obtained from the analyses of the country data included in the study show that the unemployment rate and the RGDP growth rate do not move together in the long term in these countries. This finding reveals that even if economic growth occurs in the economies of these countries, unemployment does not decrease. This situation shows that no job opportunities are emerging that can reduce unemployment with economic growth. 
This result brings jobless growth to mind. Contrary to general acceptance, economies growing without employment, although they generate a certain increase in growth rates, cannot reduce the level of unemployment. Although it varies according to the characteristics of the economies, the main reasons for jobless growth can be listed as developments in technology and changes in production methods, and the quality of labor. It is possible to say that the examined countries have different internal dynamics, although they are in the group of developing countries. For this reason, it is thought that taking into account the basic economic characteristics of each country will produce more effective results while determining the policy practices that will eliminate the jobless growth.

It is also possible to say that the problem of jobless growth arises in economies that cannot determine the economic policies to be applied in the face of changes occurring in the economic conjuncture correctly and therefore cannot provide the necessary economic transformation. For the problem to be eliminated, it is considered necessary to adopt and implement policies that will transform savings into investments and direct investments to areas that will increase employment, to regulate the policies planned to be implemented by taking into account the relationship between economic growth and unemployment. In order to solve the unemployment problem, which has started to become even deeper with the economic crises experienced, especially in terms of developing countries, countries need to develop solution-oriented economic policies by approaching the internal and external factors they are faced with together.

\section{CONFLICT OF INTEREST STATEMENT}

There is no conflict of interest between the authors (single author).

\section{FUNDING ACKNOWLEDGEMENTS}

This research received no funding from any agency in the public, commercial, or not-for-profit sectors.

\section{AUTHOR CONTRIBUTIONS}

All the contributions are made by HNTS.

11. ETHICS COMMITTEE STATEMENT AND INTELLECTUAL PROPERTY COPYRIGHTS

Ethics committee approval was not required for the study.

\section{REFERENCES}


Altunöz, U. (2015). Reel Büyüme ve İşsizlik Bağlamında Türkiye İçin Okun Yasası Analizi. Kamu $\dot{I}_{\text {ş, }} 14$ (1), 29-44.

Arı, A. (2016). Türkiye'deki Ekonomik Büyüme ve İşsizlik İlişkisinin Analizi: Yeni Bir Eşbütünleşme Testi. Siyaset, Ekonomi ve Yönetim Araştırmaları Dergisi, 4 (2), 57-67.

Arrow, K. J. (1962). The Economic Implications Of Learning By Doing. The Review Of Economic Studies, 29(3), 155-173.

Barro, R. J. (1990). Government Spending in a Simple Model of Endogenous Growth. Journal of Political Economy, 98(5), 103-125.

Barbieri, L. (2006). Panel Unit Root Tests: A Review, Quaderni del Dipartimento di Scienze Economiche E Sociali, 43, 1-53.

Barışı, S., Çevik, E. İ., \& Çevik N. K. (2010). Türkiye’de Okun Yasası, Asimetri İlişkisi ve İstihdam Yaratmayan Büyüme: Markov-Switching Yaklaşımı. Maliye Dergisi, 159, 88-102.

Binet, M.E., \& Facchini, F. (2013). Okun's Law in the French Regions: A Cross-Regional Comparison. Economics Bulletin, 33 (1), 420-433.

Christopoulos, D. K. (2004). The Relationship Between Output and Unemployment: Evidence from Greek regions. Papers in Regional Science, 83, 611-620.

Coombs, R., Saviotti, P., \& Walsh, V. (1987). Economics and Technological Change (1. Bask1). USA: Rowman \& Liitlefield Publishing.

Davidson, P. (1994). Post Keynesian Macroeconomic Theory: A Foundation for Successful Economic Policies for The Twenty-First Century. England: Edward Elgar Publishing.

Evans, G.W. (1989). Output and Unemployment Dynamics in the United States: 19501985. Journal of Applied Econometrics, 4 (3), 213-237.

Forstater, M. (2001). Unemployment in Capitalist Economies: A History of Thought for Thinking About Policy. Center For Full Employment And Price Stability, 16, 120.

Freeman, D.G. (2000). Regional Tests of Okun's Law. International Advances in Economic Research, 6 (3), 557-570.

Friedman, B.M., \& Wachter, M.L. (1974). Unemployment: Okun's Law, Labor Force and Productivity. The Review of Economics and Statistics, 56 (2), 167-176.

Friedman, M. (1977). Inflation And Unemployment. Journal Of Political Economy, 85 (3), 454-459.

Gali, J. (1999). Techonology, Employment and The Business Cycle: Do Technology Shocks Explain Aggregate Fluctuations?. American Economic Review, 89 (1), 249-271.

Gordon, R. J. (1990). What Is New-Keynesian Economics. Journal Of Economic Literature, 28 (3), 1115-1171.

Harris, R., \& Silverstone, B. (2000). Asymmetric Adjustment of Unemployment and Output in New Zealand: Rediscovering Okun's Law. Department of Economics Working Paper Series, 2/00, 1-23.

Harrison, F. E. (1996). Economic Development. USA: Praeger Publishers. 
Işık, N., \& Duman, E. (2012). 1929 Ekonomik Buhranı ve 2008 Küresel Krizi’nin Türkiye Ekonomisi Üzerindeki Etkileri. Çankırı Karatekin Üniversitesi İktisadi ve İdari Bilimler Fakültesi Dergisi, 2(1), 73-101.

Izyumov, A., \& Vahaly, J. (2002). The Unemployment-Output Tradeoff in Transition Economies: Does Okun's Law Apply?. Economics of Planning, 35 (4), $317-$ 331.

Kaldor, N. (1957). A Model of Economic Growth. The Economic Journal, 67 (268), 591624.

Keynes, J. M. (2018). The General Theory of Employment, Interest and Money. UK: Palgrave Macmillan.

Lipsey, R.G., Steiner, P. O., \& Purvis, D. D. (1984). Economics. New York: Harper and Row Publishers.

Lucas, R.E. \& Rapping L.A. (1969). Real Wages, Employment and Inflation. The University of Chicago Press Journals, 77 (5), 721-754.

Lucas, R. E. (1988). On The Mechanics Of Economic Development. Journal of Monetary Economics, 22(1), 3-42.

Marinkov M., \& Geldenhuys J.P. (2007). Cyclical Unemployment and Cyclical Output: An Estımatıon of Okun's Coefficient for South Africa. South Africa Journal of Economics, 75 (3), 373-390.

Marx, K. (2012). Das Kapital. Mehmet Selik \& Nail Satlıgan (Çev.). İstanbul: Yordam Yayınları.

Mıhçı, S., \& Atılgan E. (2010). İşsizlik ve büyüme: Türkiye ekonomisi için Okun katsayıları. Iktisat Işletme ve Finans, 25 (296), 33-54.

Modigliani, F. (1944). Liquidity Preference and the Theory of Interest and Money. Econometrica, 12 (1), 45-88.

Mucuk, M., Edirneligil, A., \& Gerçeker, M. (2017). The Relationship Between Unemployment Rate and Economic Growth: The Case of Turkey. Siyaset, Ekonomi ve Yönetim Araştırmaları Dergisi, 5(1), 1-8.

Okun, A. M. (1962). Potential Gnp: Its Measurement and Significance. In Proceedings of the Business and Economic Statistics Section of the American Statistical Association, 89-104.

Özdemir, B. K., \& Yıldırım, S. (2013). Türkiye'de Ekonomik Büyüme ve İstihdam Arasındaki Nedensellik İlişkisinin Analizi: Özçıkarımlı Dalgacık Yaklaşımı. Dumlupınar Üniversitesi Sosyal Bilimler Dergisi, 38, 97-115.

Palmerio, G. (1991). Perspectives on Economic Thought. England: Ashgate Publishing.

Patinkin, D. (1948). Price Flexibility And Full Employment. American Economic Association, 38 (4), 543-564.

Prachowny, M. F. J. (1993). Okun's Law: Theoretical Foundations And Revised Estimates. The Review of Economic And Statics, 75 (2), 331-336.

Romer, P.M. (1986). Increasing Returns and Long-Run Growt. Journal Of Political Economy, 94 (5), 1002-1037.

Ricardo, D. (1821). On The Principles Of Political Economy And Taxation. Canada: Batoche Books. 
Rodenburg, P. (2007). Derived Measurement in Macroeconomics: Two Approaches for Measuring the NAIRU Considered. Tinbergen Institute Discussion Paper, 17 (1), 1-31.

Skaggs, N.T. (1999). Adam Smith on Growth and Credit, Too Weak a Connection?. Journal of Economic Studies, 26 (6), 481-496.

Silva, S., Hadri, K., \& Tremayne A.R. (2009). Panel Unit Root Tests in the Presence of Cross-Sectional Dependence: Finite Sample Performance and an Application. The Econometrics Journal, 12 (2), 340-366.

Smith, A. (1904). The Wealth of Nations. Indianapolis: Liberty Classics.

Soylu, Ö. B., Çakmak, İ., \& Okur, F. (2018). Economic Growth and Unemployment İssue: Panel Data Analysis in Eastern European Countries. Journal of International Studies, 11(1), 93-107.

Szostak, R. (2009). The Causes of Economic Growth. Germany: Springer.

Tarı, R., \& Abasız, T. (2010). Asimetrik Etkiler Altında Okun Yasası'nın Eşik Hata Düzeltme Modeli ile Sınanması: Türkiye Örneği. İktisat İşletme ve Finans, 25 (291), 53-77.

Tcherneva, P., \& Wray L. R. (2005). Is Argentinas Job Creation Project Jefes de Hogar A True Employer of Last Resort Program?. Center for Full Employment And Price Stability, 43, 1-26.

Turan, G. (2015). Growth and Unemployment in Turkey. Munich Personal RePEc Archive, 77773, 1-15.

Viren, M. (2001). The Okun curve is non-linear. Economic Letters, 70 (2), 253-257.

Weber, C.E. (1995). Cyclical Output, Cyclical Unemployment, and Okun's Law: A new Approach. Journal of Applied Econometrics, 10 (4), 433-445.

Westerlund, J. (2007). Testing for Error Correction in Panel Data. Oxford Bulletin of Economics and Statistics, 69 (6), 709-748.

Wray, L. R. (2007). The Employer of Last Resort Programme: Could It Work for Developing Countries?. Economic And Labour Working Papers, 5, 1-46.

Yeldan, E. (2009). The Economics of Growth and Distribution. Ankara: Eflatun Yayınevi.

Zhang, W.B. (2005). Economic Growth Theory: Capital, Knowledge and Economic Structures. USA: Ashgate Publishing Company. 